\title{
Analisis Pengaruh Kinerja Keuangan Terhadap Return Saham Pada Perusahaan PT. Ramayana Lestari Sentosa Tbk
}

\author{
MUHAMAD SYAFII, SE., M.SA \\ Dosen Prodi Manajemen, STIE Port Numbay Jayapura
}

\begin{abstract}
PT. Ramayana Lestari Sentosa during 2010-2019. This type of research is in the form of quantitative descriptive, which means in this study to find out how small or large an influence is on an object under study. The analytical tool used in this research is to use the ratio of Earning Per Share, Price Earning Ratio, Debt to Equity Ratio, Return on Investment, Return on Equity, and multiple linear regression analysis. The results of this study are Earnings per Share has a positive but not significant effect on stock returns of PT. Ramayana Lestari Sentosa Tbk. This is evidenced by the results of the partial test which shows the tcount value is smaller than the ttable value and the significant value is greater than the alpha value. Price earning ratio has a positive but not significant effect on stock returns of PT. Ramayana Lestari Sentosa Tbk. This is evidenced by the results of the partial test which shows the tcount value is smaller than the ttable value and the significant value is greater than the alpha value. Return on investment has a positive but not significant effect on stock returns of PT. Ramayana Lestari Sentosa Tbk. This is evidenced by the results of the partial test which shows the tcount value is smaller than the ttable value and the significant value is greater than the alpha value. Return on equity has a positive but not significant effect on stock returns of PT. Ramayana Lestari Sentosa Tbk. This is evidenced by the results of the partial test which shows the tcount value is smaller than the ttable value and the significant value is greater than the alpha value. Earning per share, debt to equity ratio, price earning ratio, return on investment, and return on equity simultaneously have a positive but not significant effect on stock returns of PT. Ramayana Lestari Sentosa Tbk.
\end{abstract}

Keywords: Stock Return and Financial Performance

\begin{abstract}
Abstrak: Penelitian ini dilakukan untuk mengetahui secara parsial dan simultan kinerja keuangan terhadap return saham pada perusahaan PT. Ramayana Lestari Sentosa selama tahun 2010-2019. Jenis penelitian ini berbentuk deskriptif kuantitatif maksudnya dalam penelitian ini untuk mencari kecil atau besarnya suatu pengaruh terhadap suatu objek yang diteliti. Alat analisis yang digunakan dalam penelitian ini adalah dengan menggunakan rasio Earning Per Share, Price Earning Rato0, Debt to Equity Ratio, Return on Investment, Return on Equity, dan analisis regresi linear berganda. Hasil penelitian ini adalah Earning per Share berpengaruh positif tapi tidak signifikan terhadap return saham PT. Ramayana Lestari Sentosa Tbk. Hal ini dibuktikan dengan hasil uji parsial yang menunjukkan nilai $t_{\text {hitung }}$ lebih kecil dari nilai $t_{\text {tabel }}$ dan nilai signifikan lebih besar dari nilai alfa. Price earning ratio berpengaruh positif tapi tidak signifikan terhadap return saham PT. Ramayana Lestari Sentosa Tbk. Hal ini dibuktikan dengan hasil uji parsial yang menunjukkan nilai $t_{\text {hitung }}$ lebih kecil dari nilai $t_{\text {tabel }}$ dan nilai signifikan lebih besar dari nilai alfa. Return on investment berpengaruh positif tapi tidak signifikan terhadap return saham PT. Ramayana Lestari Sentosa Tbk. Hal ini dibuktikan dengan hasil uji parsial yang menunjukkan nilai $\mathrm{t}_{\text {hitung }}$ lebih kecil dari nilai $\mathrm{t}_{\text {tabel }}$ dan nilai signifikan lebih besar dari nilai alfa. Return on equity berpengaruh positif tapi tidak signifikan terhadap return saham PT. Ramayana Lestari Sentosa Tbk. Hal ini dibuktikan dengan hasil uji parsial yang menunjukkan nilai $t_{h i t u n g}$ lebih kecil dari nilai $\mathrm{t}_{\text {tabel }}$ dan nilai signifikan lebih besar dari nilai alfa. Earning per share, debt to equity ratio, price earning ratio, return on investment, dan return on equity secara simultan berpengaruh positif tapi tidak signifikan terhadap return saham PT. Ramayana Lestari Sentosa Tbk.
\end{abstract}

Kata kunci : Return Saham dan Kinerja Keuangan

\section{PENDAHULUAN}

Di pasar modal, laporan keuangan perusahaan yang go public sangat penting sebagai dasar penilaian kinerja keuangan perusahaan, terlebih perusahaan yang go public merupakan perusahaan yang dimiliki oleh perusahaan luas, oleh karena itu operasi perusahaan yang efisien akan sangat mempengaruhi apresiasi masyarakat pada perusahaan publik. Secara umum nilai perusahaan digambarkan dengan adanya perkembangan harga saham perusahaan di pasar modal. Semakin tinggi harga saham suatu perusahaan, maka semakin tinggi pula nilai perusahaan tersebut. Harga saham di pasar modal dipengaruhi oleh beberapa faktor antara lain, kinerja perusahaan secara keseluruhan khususnya prospek perusahaan di masa depan serta laba yang dihasilkan.
Selain 9 im As detsiden yang dibagikan kepada pemegang saham, suku bunga bank, serta tingkat perubahan harga dianggap cukup berpengaruh. Dan seluruh faktor fundamental tersebut dipengaruhi oleh kondisi perekonomian pada umumnya.

Saham adalah salah satu asset yang diperdagangkan oleh perusahaan dalam pasar modal. Pasar modal merupakan salah satu fasilitas untuk menyalurkan dana dari pihak yang memiliki kelebihan dana kepada pihak yang membutuhkan dana. Dengan melonjaknya jumlah saham yang ditransaksikan, serta semakin tinggi volume perdagangan saham, akan mendorong perkembangan pasar modal di Indonesia. Seiring dengan perkembangan tersebut, maka kebutuhan akan informasi dalam pengambilan keputusan investasi di pasar modal juga akan meningkat. Sehingga investor harus 
mempertimbangkan kinerja perusahaan tersebut dalam pengambilan keputusan investasi. Informasi yang berhubungan dengan kinerja atau kondisi perusahaan umumnya ditunjukkan dalam laporan keuangan. Dimana laporan keuangan menyediakan informasi keuangan perusahaan, hal ini sebagaimana dalam Standar Akuntansi Keuangan (SAK) menyatakan bahwa tujuan laporan keuangan adalah menyediakan informasi yang menyangkut posisi keuangan, kinerja, serta perubahan posisi keuangan suatu perusahaan yang bermanfaat bagi sejumlah besar pengguna pengambilan keputusan ekonomi.

Analisis rasio keuangan didasarkan pada data keuangan historis yang tujuan utamanya adalah memberi suatu indikasi kinerja perusahaan pada masa yang akan datang. Analisis rasio keuangan merupakan suatu alternatif untuk menguji apakah informasi keuangan yang dihasilkan oleh akuntansi keuangan bermanfaat untuk melakukan klasifikasi atau prediksi terhadap return saham di pasar modal. Dengan analisis rasio keuangan dapat diketahui kekuatan dan kelemahan perusahaan di bidang keuangan, namun dapat juga dipakai sebagai sistem peringatan awal (early warning system) terhadap kemunduran kondisi keuangan perushaan yang mengakibatkan tidak akan memberikan kepastian going concern perusahaan khususnya untuk perusahaan yang go public. Untuk bisa menarik calon investor, perusahaan harus mampu menunjukkan kinerjanya dengan rasio keuangan. Investor sebelum melakukan investasi pada perusahaan yang terdaftar di BEI melakukan analisis kinerja perusahaan antara lain menggunakan rasio keuangan sehingga kinerja keuangan perusahaan berkaitan dengan return perusahaan (Husnan, 2003:44). Dengan analisis rasio ini perusahaan dapat lebih mudah melihat tren perusahaan serta melakukan prediksi di masa yang akan datang.

Dalam keputusan investasi para pemodal tidak hanya memperhatikan tingkat keuntungan yang diharapkan tetapi risiko investaski. Secara intuitif tentunya ada hubungan positif antara tingkat keuntungan dan risiko. Investor akan memanfaatkan semua informasi dan kinerja keuangan perusahaan terhadap harga pada pengambilan keputusan beli atau jual saham sekarang merefleksikan semua informasi yang diketahui.

PT. Ramayana Lestari Sentosa, Tbk merupakan salah satu perusahaan yang bergerak dalam bidang bisnis rantai toko swalayan yang ada di Indonesia. Jaringan toko yang dirintis oleh pasangan suami istri Paulus Tumewu dan Tan Lee Chuan ini pertama kali dibuka pada tahun 1978. Pada semester pertama 2015 kondisi keuangan perusahaan sempat mengalami kesulitan karena penjualan dihampir semua toko abnormal/tidak sebagaimana biasanya dan situasi diluar pulau Jawa benar-benar suram. Namun pada tahun 2018 total pendapatan perusahaan mencapai $\mathrm{Rp}$ 8.539 miliar. Pendapatan naik jika dibandingkan dengan pendapatan tahu sebelumnya ditahun 2017 yaitu Rp 8.146 miliar. Sementara pertumbuhan bisnis perusahaan secara keseluruhan mencapai $4,8 \%$ sementara kinerja penjualan berhasil membukukan tingkat pertumbuhan $44 \%$ dari jumlah laba bersih. Perusahaan juga membukukan kenaikan laba kotor sebesar 13,3\% menjadi Rp 2.507 miliar, dibandingkan dengan Rp 2.212 miliar yang dibukukan pada tahun sebelumnya.

Berdasarkan penjelasan di atas maka penulis tertarik untuk meneliti mengenai kinerja keuangan terhadap harga return saham sebagai objek penelitian yang berjudul "Pengaruh Kinerja Keuangan Terhadap Return Saham Pada PT. Ramayana Lestari Sentosa, Tbk".

\section{KONSEP TEORI \\ Laporan Keuangan}

Laporan keuangan pada hakekatnya merupakan hasil dan proses akuntansi yang disusun menurut prinsipprinsip akuntansi yang berlaku umum yang dapat digunakan untuk mengkomunikasikan data keuangan kepada pihak yang berkepentingan. Menurut Ikatan Akuntan Indonesia (2009:1) disebutkan laporan keuangan merupakan bagian dari proses pelaporan keuangan. Laporan keuangan yang lengkap biasanya meliputi neraca, laporan laba rugi, dan laporan perubahan posisi keuangan (yang disajikan dalam berbagai cara seperti, misalnya sebagai laporan arus kas atau laporan arus dana), catatan dan laporan lain, serta materi penjelasan merupakan bagian integral dari laporan keuangan. Menurut Soemarso (2004:34), laporan keuangan adalah laporan yang dirancang untuk para pembuat keputusan, terutama pihak di luar perusahaan, mengenai posisi keuangan dan hasil usaha perusahaan. Sementara Sundjaya dan Barlian (2001:47) laporan keuangan adalah suatu laporan yang menggambarkan hasil dan proses akuntansi yang digunakan sebagai alat komunikasi untuk pihak-pihak yang berkepentingan dengan data keuangan atau aktivitas perusahaan.

\section{Rasio Keuangan}

Menurut Nainggolan (2004:68) ada beberapa rasio keuangan yang digunakan untuk mengukur kinerja keuangan perusahaan, yaitu: a). EPS (Earning per Share), merupakan laba yang diperoleh perusahaan per lembar saham. Laba per saham merupakan alat ukur yang berguna untuk membandingkan laba dari berbagai entitas usaha yang berbeda dan untuk membandingkan laba suatu entitas dari waktu ke waktu jika terjadi perubahan dalam struktur modal. Laba per saham telah sejak dulu dihitung dan digunakan oleh para analis keuangan. Perhitungan laba per saham yang mengarah ke masa depan mencoba memberikan informasi mengenai laba per saham yang mungkin akan diperoleh di mada datang, b). DER (Debt to Equity Ratio), merupakan rasio yang mengukur besarnya hutang yang ditanggung melalui modal sendiri yang dimiliki perusahaan. Debt to equity ratio adalah instrument untuk mengetahui kemampuan akuitas atau aktiva bersih suatu perusahaan untuk melunasi seluruh kewajibannya, c). PER (Price Earning Ratio) Menurut Rahardjo (2003) rasio harga dengan penghasilan atau price earning ratio sering digunakan untuk membandingkan peluang investasi. Suatu rasio harga dan penghasilan saham dihitung dengan membagi harga pasar per lembar saham (market price share) dengan penghasilan per lembar saham (PER), d). 
ROI (Return on Investment) merupakan rasio untuk mengukur kemampuan manajemen dalam menghasilkan pendapatan dari pengelolaan asset (Kasmir, 2003). e). ROE (Return on Equity) merupakan rasio untuk mengukur kemampuan manajemen bank dalam mengelola modal yang ada untuk mendapatkan net income (Kasmir, 2003).

\section{Saham}

Saham adalah penyertaan dalam modal dasar suatu perseroan terbatas, sebagai tanda bukti penyertaan tersebut dikeluarkan surat kolektif kepada pemilik yaitu pemegang saham. Saham merupakan salah satu pilihan perusahaan ketika memutuskan untuk pendanaan perusahaan. Pada sisi lain, saham merupakan instrumen investasi yang banyak dipilih para investor karena saham mampu memberikan tingkat keuntungan yang menarik. Saham dapat didefinisikan sebagai tanda penyertaan modal seseorang atau pihak (badan usaha) dalam suatu perusahaan atau perseroan terbatas. Dengan penyertaan modal tersebut, maka pihak tersebut memiliki klaim atas pendapatan perusahaan, klaim atas asset perusahaan, dan berhak hadir dalam Rapat Umum Pemegang Saham (RUPS). Adapun jenis-jenis saham menurut Riyanto (1995:241) adalah sebagai berikut: 1) Saham Biasa (Common Stock). Pemegang saham biasa hanya akan mendapat dividen pada akhir tahun pembukuan, hanya kalau perusahaan tersebut mendapatkan keuntungan. Apabila perusahaan tersebut mendapat kerugian, maka pemegang saham tidak akan mendapat divide dan mengenai hal ini ada ketentuan hukumnya, yaitu bahwa suatu perusahaan yang menderita kerugian, selama kerugian itu belum dapat ditutup, maka selama itu perusahaan tidak diperbolehkan membayar dividen. 2) Saham Preferen (Prefered Stock) . Pemegang saham preferen mempunyai beberapa "preferensi" tertentu dibandingkan dengan pemegang saham biasa.

\section{Return Saham}

Return Saham. Return merupakanhasil yang diperoleh dari sebuah investasi. Return dapat berupa return realisasi (realized return) yaitu return yang telah terjadi atau return ekspektasi (expected return) yaitu return yang diharapkan akan terjadi di masa yang akan datang. Hartono (2000:107) menyatakan bahwa return abnormal (abnormal return) merupakan selisih antara return ekspektasi dan return realisasi. Saham suatu perusahaan bisa dinilai dari pengembalian (return) yang diterima oleh pemegang saham dari perusahaan yang bersangkutan. Return bagi pemegang saham bisa berupa penerimaan dividen tunai ataupun adanya perubahan harga saham pada suatu periode (Beza, 1988).

Return abnormal menjadi indikator untuk mengukur efisiensi suatu pasar modal. Apabila harga suatu instrumen investasi telah mencerminkan seluruh informasi yang ada maka return ekspektasi atas suatu harga saham relatif akan sama dengan return realisasinya. Untuk melakukan investasi dalam bentuk saham diperlukan analisis untuk mengukur nilai saham, yaitu analisis fundamental dan analisis teknikal. Tujuan analisis fundamental adalah menentukan apakah nilai saham berada pada posisi undervalue atau overvalue. Saham dikatakan undervalue bilamana return saham di pasar modal lebih kecil dari harga wajar atau nilai yang seharusnya, demikian juga sebaliknya. Dapat dikatakan bahwa untuk memperkirakan return saham dapat menggunakan analisa fundamental yang menganalisa kondisi keuangan dan ekonomi perusahaan yang menerbitkan saham twersebut. Analisis fundamental berkaitan dengan penelaian kinerja perusahaan, tentang efektifitas dan efisiensi perusahaan mencapai sasarannya (Foster: 1986). Untuk menganalisis kinerja perusahaan dapat digunakan rasio keuangan yang terbagi dalam empat kelompok, yaitu rasio likuiditas, aktivitas, hutang, dan profitabilitas (Kim, 1991).

Berdasarkan latar belakang di atas maka hipotesis dalam penelitian ini adalah:

$\mathrm{H}_{1}$ : Earning Per Share (EPS), Debt to Equity Ratio (DER), Price Earning Ratio (PER), Return on Investment (ROI), dan Return on Equity (ROE) secara parsial mempunyai pengaruh yang signifikan terhadap Return Saham.

$\mathrm{H}_{2}$ : Earning Per Share (EPS), Debt to Equity Ratio (DER), Price Earning Ratio (PER), Return on Investment (ROI), dan Return on Equity (ROE) secara bersama-sama mempunyai pengaruh yang signifikan terhadap Return Saham.

\section{METODE}

Penelitian yang dilakukan menggunakan desain kausal. Desain kausal berguna untuk menganalisis hubungan antara satu variabel dengan variabel lainnya atau bagimana suatu variabel mempengaruhi variabel lainnya (Umar, 2006:63). Variabel terdiri dari variabel bebas (independent variable) dan variabel terikat (dependent variable). Variabel bebas adalah EPS, PER, DER, ROI, dan ROE dan variabel terikat adalah Return Saham. Dalam penelitian ini untuk mengetahui pengaruh rasio keuangan Earning Per Share (EPS), Price Earning Ratio (PER), Debt to Equity Ratio (DER), Return on Investment (ROI), dan Return on Equity (ROE) baik secara parsial maupun secara bersama-sama terhadap Return Saham pada PT. Ramayana Lestari Sentosa, Tbk.

Data yang digunakan dalam penelitian ini adalah data sekunder. Data sekunder adalah data yang diolah bersumber dari dari perusahaan yang diteliti. Penelitian ini menggunakan data sekunder yang berupa laporan keuangan yaitu neraca, laporan laba rugi perusahaan dan catatan atas laporan keuangan perusahaan yang sumbernya diambil dari Bursa Efek Indonesia melalui Pusat Informasi Pasar Modal (PIPM) Jayapura, Website www.idx.co.id, Website www.icmd.co.id, dan www.sahamok.com. Adapun data keuangan yang akan digunakan adalah laporan keuangan dan data return saham PT. Ramayana Lestari Sentosa, Tbk periode 2010-2019.

Teknik analis data yang digunakan adalah penelitian ini analisis regresi linier berganda. Analisis data dalam penelitian ini menggunakan analisis regresi linier berganda, yaitu menganalisis data berdasarkan uji statistik sehingga dapat diukur besarnya pengaruh variabel bebas 
terhadap variabel terikat. Dalam hal ini peneliti menggunakan program komputer SPSS. Formula yang digunakan (Sugiono, 2003:234):

Dimana:

$\mathrm{Y}=\mathrm{a}+\mathrm{b}_{1} \mathrm{X}_{1}+\mathrm{b}_{2} \mathrm{X}_{2}+\mathrm{b}_{3} \mathrm{X}_{3}+\mathrm{b}_{4} \mathrm{X}_{4}+\mathrm{e}$.

$\mathrm{Y} \quad=$ Return Saham

$\mathrm{X}_{1} \quad=$ EPS (Earning Per Share)

$\mathrm{X}_{2} \quad=$ PER (Price Earning Ratio)

$\mathrm{X}_{3} \quad=$ DER (Debt Earning Ratio)

$\mathrm{X}_{4} \quad=\mathrm{ROI}($ Return on Investment $)$

$\mathrm{X}_{5} \quad=\mathrm{ROE}$ (Return on Equity)

$\mathrm{b}_{1}-\mathrm{b}_{2} \quad=$ Koefisien regresi

$\mathrm{a} \quad=$ Konstanta

e $\quad=$ Standar error

\section{HASIL}

Berdasarkan hasil pengumpulan data melaui beberapa web site, dan hasil perhitungan nilai rasio yang berkaitan dengan pengaruh Earning Per Share (EPS), Price Earning Ratio (PER), Debt to Equity Ratio (DER), Return on Investment (ROI), dan Return on Equity (ROE) terhadap Return Saham PT. Ramayana Lestari Sentosa, Tbk periode 2010-2019, maka diperoleh hasil sebagai berikut:

\section{Analisis Regresi Linier Berganda}

Setelah mendapatkan data mengenai EPS $\left(\mathrm{X}_{1}\right)$, PER $\left(\mathrm{X}_{2}\right)$, DER $\left(\mathrm{X}_{3}\right)$, ROI $\left(\mathrm{X}_{4}\right)$, ROE $\left(\mathrm{X}_{5}\right)$ dan Return Saham (Y), maka selanjutnya dilakukan pengolahan data dengan aplikasi SPSS for Windows, dengan hasil, didapatkan persamaan regresi linier berganda $\mathrm{Y}=$ $4,567+0,029 X_{1}+0,089 X_{2}+0,043 X_{3}+0,097 X_{4}+0,222 X_{5}$ $+\mathrm{e}$.

Keterangan:

a) Konstanta sebesar 4,567 menunjukkan bahwa apabila tidak ada variabel independen (EPS, PER, DER, ROI, ROE) maka tingkat return saham akan mengalami penurunan sebesar 4,567.

b) Koefisien regresi $b_{1}$ sebesar 0,029 menunjukkan bahwa setiap penambahan Earning Per Share (EPS) sebesar 1\% maka akan diikuti oleh besarnya nilai Return saham sebesar 0,029 dengan asumsi variabel lain tetap.

c) Koefisien regresi $b_{2}$ sebesar 0,089 menunjukkan bahwa setiap penambahan Price Earning Ratio (PER) sebesar 1\% maka akan diikuti oleh besarnya nilai Return saham sebesar 0,089 dengan asumsi variabel lain tetap.

d) Koefisien regresi $b_{3}$ sebesar 0,043 menunjukkan bahwa setiap penambahan Debt to Equity Ratio (DER) sebesar $1 \%$ maka akan diikuti oleh besarnya nilai Return saham sebesar 0,043 dengan asumsi variabel lain tetap.

e) Koefisien regresi $b_{4}$ sebesar 0,097 menunjukkan bahwa setiap penambahan Return on Investment (ROI) sebesar $1 \%$ maka akan diikuti oleh besarnya nilai Return saham sebesar 0,097 dengan asumsi variabel lain tetap.

f) Koefisien regresi $b_{5}$ sebesar 0,222 menunjukkan bahwa setiap penambahan Return on Equity (ROE) sebesar 1\% maka akan diikuti oleh besarnya nilai Return saham sebesar 0,222 dengan asumsi variabel lain tetap.
Uji t (t Test)

Uji signifikan individual atau yang lebih dikenal dengan uji statistik $\mathrm{T}$ merupakan proses aqnalisis data secara parsial. Uji T ini nantinya akan menunjukkan berapa banyak pengaruh variabel independen secara parsial terhadap variabel dependen. Uji T tujuannya untuk melihat sejauh mana pengaruh secara parsial dari variabel bebas terhadap variabel terikat. Uji $\mathrm{T}$ lebih sering digunakan untuk data yang jumlahnya lebih sedikit yaitu kurang dari 30. Selain itu, uji T digunakan jika nilai parameter sudah diketahui (ditentukan) dan data terdistribusi normal. Caranya dengan membandingkan $t_{\text {tabel }}$ dengan $t_{\text {hitung. Setiap }}$ nilai $\mathrm{T}$ hasil perhitungan, akan dibandingkan $\mathrm{T}$ table yang didapatkan menggunakan taraf nyata (biasanya 0,05 ).

Berdasarkan hasil pengolahan data diperoleh $t_{\text {hitung }}$ dan nilai signifikansi variabel-variabel bebas dengan nilai $\mathrm{t}_{\text {tabel }}$ dalam penelitian ini adalah 2,7745 $(\mathrm{df}=4)$ dengan tingkat signifikansi sebesar 0,05, dengan demikian maka:

a. Earning per share $\left(\mathrm{X}_{1}\right)$ berpengaruh positif tidak signifikan terhadap Return saham. Hal ini dibuktikan dengan nilai $t_{\text {hitung }}$ lebih kecil dari nilai $t_{\text {tabel }}(0,635<$ 2,77645) dan nilai signifikansi sebesar 0,560 lebih besar dari 0,05. Dengan demikian maka hipotesis tentang "Earning Per Share (EPS) berpengaruh signifikan terhadap Return Saham" ditolak.

b. Price Earning Ratio $\left(\mathrm{X}_{2}\right)$ berpengaruh positif tidak signifikan terhadap Return saham. Hal ini dibuktikan dengan nilai $\mathrm{t}_{\text {hitung }}$ lebih kecil dari nilai $\mathrm{t}_{\text {tabel }}(0,830<$ 2,77645) dan nilai signifikansi sebesar 0,453 lebih besar dari 0,05. Dengan demikian maka hipotesis tentang "Price Earning Ratio (PER) berpengaruh signifikan terhadap Return Saham" ditolak.

c. Debt to Equity Ratio $\left(\mathrm{X}_{3}\right)$ berpengaruh positif tidak signifikan terhadap Return saham. Hal ini dibuktikan dengan nilai $t_{\text {hitung }}$ lebih kecil dari nilai $t_{\text {tabel }}(0,222<$ 2,77645) dan nilai signifikansi sebesar 0,835 lebih besar dari 0,05. Dengan demikian maka hipotesis tentang "Debt to Equity Ratio (DER) berpengaruh signifikan terhadap Return Saham" ditolak.

d. Return on Investment $\left(\mathrm{X}_{4}\right)$ berpengaruh positif tidak signifikan terhadap Return saham. Hal ini dibuktikan dengan nilai $t_{\text {hitung }}$ lebih kecil dari nilai $t_{\text {tabel }}(0,262<$ 2,77645) dan nilai signifikansi sebesar 0,806 lebih besar dari 0,05. Dengan demikian maka hipotesis tentang "Return on Investment (ROI) berpengaruh signifikan terhadap Return Saham" ditolak.

e. Return on Equity $\left(\mathrm{X}_{5}\right)$ berpengaruh positif tidak signifikan terhadap Return saham. Hal ini dibuktikan dengan nilai $t_{\text {hitung }}$ lebih kecil dari nilai $t_{\text {tabel }}(0,517<$ 2,77645) dan nilai signifikansi sebesar 0,632 lebih besar dari 0,05. Dengan demikian maka hipotesis tentang "Return on Equity (ROE) berpengaruh signifikan terhadap Return Saham" ditolak.

\section{Uji F atau Uji Serempak}

Uji F digunakan untuk mengetahui pengaruh variabel bebas secara bersama-sama atau simultan terhadap variabel terikat. Uji F dikenal dengan Uji serentak atau uji Mode/Uji Anova, yaitu uji untuk melihat pengaruh semua 
variabel bebasnya secara bersama-sama terhadap variabel terikat. Atau untuk menguji apakah model regresi yang kita buat baik/signifikan atau tidak baik/non signifikan. Kriteria pengambilan keputusan jika nilai $F_{\text {hitung }}$ lebih besar dari $F_{\text {tabel }}$ dan nilai signifikansinya lebih kecil dari $\sigma=0,05$ maka variabel bebas berpengaruh secara simultan terhadap variabel terikat.

Berdasarkan hasil pengolahan data dengan aplikasi SPSS for Windows diperoleh hasil nilai $\mathrm{F}_{\text {tabel }}$ dalam penelitian ini adalah sebesar 6,26 $\left(\mathrm{df}_{1}=5 \mathrm{dan} \mathrm{df}_{2}=4\right)$. Maka berdasarkan ketentuan uji simultan, diketahui bahwa nilai $F_{\text {hitung }}$ lebih kecil dari nilai $F_{\text {tabel }}$, yaitu 1,271 $<6,26$, dengan nilai signifikannya lebih besar dari 0,420 yaitu $1,271>0,05$. Dengan demikian maka dapat disimpulkan bahwa hipotesis mengenai Earning Per Share (EPS), Price Earning Ratio (PER), Debt to Equity Ratio (DER), Return on Investment (ROI), dan Return on Equity (ROE) secara bersama-sama mempunyai pengaruh yang signifikan terhadap Return, ditolak.

\section{Analisis Koefisien Korelasi dan Koefisien Determinasi}

Nilai koefisien korelasi (R) menunjukkan seberapa besar korelasi atau hubungan antara variabelvariabel independen dengan variabel dependen. Koefisien korelasi dikatakan kuat apabila nilai $\mathrm{R}$ berada di atas 0,5 dan mendekati 1.

Koefisien determinasi ( $R$ square) menunjukkan seberapa besar variabel independen menjelaskan variabel dependennya. Nilai $R$ square adalah nol sampai dengan satu. Apakah nilai $R$ square semakin mendekati satu, maka variabel-variabel independen memberikan semua informasi yang dibutuhkan untuk memprediksi variasi variabel dependen. Sebaliknya, semakin kecil nilai $R$ square, maka kemampuan variabel-variabel independen dalam menjelaskan variasi variabel dependen semakin terbatas.

Pada model summary, nilai koefisien korelasi (R) sebesar 0783 yang berarti bahwa korelasi atau hubungan antara Return saham (Y) dengan variabel independen (EPS, PER, DER, ROI, ROE) kuat karena berada di antara 0,70 0,79 . Angka $\mathrm{R}_{\text {adjust }} R$ square atau koefisien determinasi adalah 0,131 . Hal ini berarti $13,1 \%$ variasi atau perubahan dalam Return saham dapat dijelaskan oleh variabel dari earning per share, price earning ratio, debt to equity ratio, return on investment, dan return on equity, sedangkan sisanya $86,9 \%$ dipengaruhi oleh variabel lain yang tidak diteliti dalam penelitian ini.

\section{PEMBAHASAN}

1. Pengaruh Earning per Share terhadap Rerturn saham

Dari penjelasan uji $\mathrm{t}$ diatas diketahui bahwa Earning per share $\left(\mathrm{X}_{1}\right)$ berpengaruh positif tidak signifikan terhadap Return saham. Hal ini dibuktikan dengan nilai $t_{\text {hitung }}$ lebih kecil dari $t_{\text {tabel }}(0,635<2,77645)$ dan nilai signifikansi sebesar 0,560 lebih besar dari 0,05. Artinya, setiap setiap perubahan earning per share akan mempengaruhi perubahan pada return saham tapi tidak signifikan. Hasil ini sama xdengan yang diperoleh Sonya Krisnawati (2009), dimana variabel Earning per share memiliki pengaruh yang positif tetapi tidak signifikan terhadap return saham.

Hal ini disebabkan karena kemampuan perusahaan dalam menggunakan asset yang dimilikinya kurang efektif, sehingga mengakibatkan laba yang diperoleh sangat rendah. Berdasarkan teori yang mendasarinya bahwa Earning per Share yang semakin besar akan menunjukkan bahwa kemampuan perusahaan dalam menghasilkan laba bersih setelah pajak semakin meningkat, dengan meningkatnya laba bersih setelah pajak yang dihasilkan oleh perusahaan maka total return yang diterima para pemegang saham juga semakin meningkat. Namun sebaliknya Namun sebaliknya jika Earning per Share semakin kecil Earning per Share maka kemungkinan semakin kecil pula laba yang dibagikan kepada para investor. Hal ini berarti tingkat return saham lebih banyak dipengaruhi oleh faktor lainnya selain Earning per Share.

2. Pengaruh price earning ratio terhadap Return saham Berdasarkan hasil uji $\mathrm{t}$ dapat dilihat bahwa variabel price earning ratio berpengaruh positif tidak signifikan terhadap Return saham. Hal ini dibuktikan dengan nilai $t_{\text {hitung }}$ lebih kecil dari nilai $t_{\text {tabel }}(0,830<$ 2,77645) dan nilai signifikansi sebesar 0,453 lebih besar dari 0,05 . Artinya, setiap perubahan price earning ratio akan mempengaruhi perubahan pada return saham tapi tidak siginifikan. Hasil ini sama dengan hasil yang diperoleh Sonya Krisnawati (2009), dimana variabel price earning ratio memiliki pengaruh yang positif tetapi tidak signifikan terhadap return saham.

Rasio yang digunakan untuk mengukur jumlah uang yang dibayarkan oleh penanam modal untuk setiap rupiah pendapatan perusahaan adalah Price Earning Ratio (PER). Semakan rendah Price Earning Ratio (PER) perusahaan berarti saham perusahaan tidak dapat memberikan return yang besar bagi investor, semakin rendah kepercayaan investor terhadap masa depan perusahaan atas pemberian hasil investasi. Price Earning Ratio (PER) digunakan oleh para investor untuk memprediksi kemampuan perusahaan dalam menghasilkan laba di masa yang akan datang. Investor dapat mempertimbangkan rasio ini untuk memilahmilah saham mana yang nantinya dapat memberikan keuntungan yang besar dimasa mendatang. Price Earning Ratio (PER) menunjukkan hubungan antara harga pasar saham biasa dengan earning per share. Tingkat keuntungan yang tinggi menandakan pertumbuhan perusahaan dari masa mendatang. Perusahaan dengan peluang tingkat pertumbuhan yang rendah biasanya mempunyai Price Earning Ratio (PER) yang rendah, demikian pula sebaliknya perusahaan dengan pertumbuhan yang tinggi memiliki Price Earning Ratio (PER) yang tinggi. Price Earning Ratio $(P E R)$ merupakan bagian dari rasio pasar dari sudut pandang investor dan juga merupakan ukuran untuk menentukan bagaimana pasar memberi harga pada saham suatu perusahaan. 
3. Pengaruh debt to equity ratio terhadap Return saham

Dari penjelasan uji t diatas diketahui bahwa Debt to Equity Ratio (DER) berpengaruh positif tidak signifikan terhadap Return saham. Hal ini dibuktikan dengan nilai $t_{\text {hitung }}$ lebih kecil dari nilai $t_{\text {tabel }}(0,222<$ 2,77645) dan nilai signifikansi sebesar 0,835 lebih besar dari 0,05 .. Artinya, setiap perubahan debt to equity ratio akan berpengaruh pada perubahan return saham tetapi tidak signifikan. Hasil penelitian ini sesuai dengan hasil penelitian yang dilakukan oleh Sonya Krisnawati (2009), yaitu Debt to Equity Ratio memiliki pengaruh positif tetapi tidak signifikan terhadap return saham, akan tetapi bertolak belakang dengan hasil penelitian yang dilakukan oleh Dyah (2007), dimana variabel Debt to Equity Ratio tidak memiliki pengaruh signifikan terhadap return saham.

Debt to equity ratio (DER) dipergunakan untuk mengukur tingkat penggunaan utang terhadap shareholder' equity yang dimiliki perusahaan. Total debt merupakan total liabilities (utang jangka Pendek/ uatang jangka panajang), sedangkan total shareholder menunjukan total modal sendiri yang dimiliki perusahaan. Semakin tinggi debt to equity ratio (DER) menunjukan kinerja keuangan perusahaan tidak baik, karena tingkat hutang yang dimiliki perusahaan semakin tinggi berarti beban bunga akan semakin besar yang berarti akan mengurangi keuntungan, sehingga return akan menjadi kecil.

4. Pengaruh return on investment terhadap return saham

Dari penjelasan uji $\mathrm{t}$ diatas dapat dilihat bahwa Return on Investment (ROI) berpengaruh positif tidak signifikan terhadap Return saham. Hal ini dibuktikan dengan nilai $t_{\text {hitung }}$ lebih kecil dari nilai $t_{\text {tabel }}(0,262<$ 2,77645) dan nilai signifikansi sebesar 0,806 lebih besar dari 0,05. Dalam pengujian hipotesis yang dilakukan, diketahui bahwa return on investment berpengaruh positif dan tidak signifikan terhadap return saham. Hasil penelitian ini sejalan dengan penelitian yang dilakukan oleh Sonya Krisnawati (2009), dimana pada hasil penelitiannya return on investment memiliki pengaruh positif tetapi tidak signifikan terhadap return saham.

Return on Investment adalah net earning power ratio. Return on Investment adalah kemampuan dari modal yang diinvestasikan dalam keseluruhan aktiva untuk menghasilkan keuntungan bersih. Selain itu, Return on Investment didefinisikan oleh Lukman Syamsuddin (1992: 63) adalah sebagai berikut Return on Investment merupakan pengukuran kemampuan perusahaan secara keseluruhan dalam menghasilkan keuntungan dengan jumlah keseluruhan aktiva yang tersedia di perusahaan. Peningkatan laba ini mempunyai efek yang positif terhadap kinerja keuangan perusahaan dalam pencapaian tujuan untuk memaksimalkan nilai perusahaan yang akan direspon secara positif oleh investor sehingga permintaan saham perusahaan dapat meningkat dan dapat menaikan harga saham perusahaan.

\section{Pengaruh return on equity terhadap return saham}

Dari penjelasan uji $\mathrm{t}$ dapat dilihat bahwa variabel Return on Equity (ROE) berpengaruh positif tidak signifikan terhadap Return saham. Hal ini dibuktikan dengan nilai $t_{\text {hitung }}$ lebih kecil dari nilai $t_{\text {tabel }}$ $(0,517<2,77645)$ dan nilai signifikansi sebesar 0,632 lebih besar dari 0,05. Dalam pengujian hipotesis yang dilakukan, diketahui bahwa return on equity berpengaruh positif dan tidak signifikan terhadap return saham. Hasil penelitian ini bertolak belakang dengan penelitian yang dilakukan oleh Sonya Krisnawati (2009), dimana pada hasil penelitiannya return on equity pengaruh negatif dan tidak signifikan terhadap return saham.

Tidak signifikannya pengaruh return on equity ini terjadi karena kemampuan perusahaan dalam menciptakan laba yang dihasilkan dari modal masih kurang kecil. Dengan jumlah equity (modal) yang tinggi maka mengakibatkan banyak dana yang kurang produktif sehingga perlu adanya pengalokasian dana yang dapat menghasilkan keuntungan. Dengan kondisi seperti ini investor akan menilai bahwa perusahaan masih kurang baik dalam mengelola dananya. Hal ini memberikan indikasi bahwa tingkat pengembalian investasi yang akan diterima investor rendah, sehingga investor tidak tertarik dalam membeli saham.

Semakin tinggi return on equity, maka semakin baik produktivitas aset dalam memperoleh laba, dan tingkat pengembalian akan semakin besar". Tetapi kinerja keuangan perusahaan masih dinilai kurang efektif dalam menghasilkan laba. Dengan demikian, hal ini dapat mempengaruhi minat investor dalam menanamkan modalnya pada perusahaan yang akan berdampak pada menurunnya return saham

6. Pengaruh Earning Per Share (EPS), Debt to Equity Ratio (DER), Price Earning Ratio (PER), Return on Investment (ROI), dan Return on Equity (ROE) secara simultan terhadap Return Saham

Dari hasil pengujian secara simultan dalam penelitian ini, diketahui bahwa Earning Per Share (EPS), Debt to Equity Ratio (DER), Price Earning Ratio (PER), Return on Investment (ROI), dan Return on Equity (ROE) secara simultan tidak memiliki pengaruh yang signifikan terhadap return saham. Hal ini konsisten dengan penelitian yang dilakukan oleh Sonya Krisnawati (2009), yang menyatakan bahwa earning per share, debt to equity ratio, price earning ratio, return on investment, dan return on equity secara bersamasama tidak berpengaruh terhadap variabel dependen (return saham).

Hasil ini juga diperkuat dengan nilai koefisien determinasi, yang menunjukkan bahwa Radjust $R$ square atau koefisien determinasi adalah 0,131 . Hal ini berarti bahwa earning per share, price earning ratio, debt to equity ratio, return on investment, dan return on equity, hanya memberikan kontribusi pengaruh sebesar $13,1 \%$ terhadap return saham PT. Ramayana Lestari Sentosa Tbk, sedangkan sisanya $86,9 \%$ dipengaruhi oleh variabel lain yang tidak diteliti dalam penelitian 
ini.

Sebagaimana kita ketahui bahwa, selain Earning Per Share (EPS), Debt to Equity Ratio (DER), Price Earning Ratio (PER), Return on Investment (ROI), dan Return on Equity (ROE), masih ada faktor yang mempengaruhi nilai return saham. Menurut Samsul (2006: 200), faktor-faktor yang mempengaruhi return saham terdiri atas faktor makro dan faktor mikro.

a. Faktor makro yaitu faktor yang berada di luar perusahaan, yaitu:

a) Faktor makro ekonomi yang meliputi tingkat bunga umum domestik, tingkat inflasi, kurs valuta asing dan kondisi ekonomi internasional.

b) Faktor non ekonomi yang meliputi peristiwa politik dalam negeri, peristiwa politik di luar negeri, peperangan, demonstrasi massa dan kasus lingkungan hidup.

b. Faktor mikro yaitu faktor yang berada di dalam perusahaan itu sendiri, yaitu:
a)Laba bersih per saham
b) Nilai buku per saham
c) Rasio utang terhadap ekuitas
d) Dan rasio keuangan lainnya.

\section{KESIMPULAN}

Berdasarkan hasil penelitian diatas dapat disimpulkan: (1) Earning per Share berpegaruh positif tapi tidak signifikan terhadap return saham PT. Ramayana Lestari Sentosa Tbk. Hal ini dibutkikan dengan hasil uji parsial yang menunjukkan nilai $t_{\text {hitung }}$ lebih kecil dari nilai $\mathrm{t}_{\text {tabel }}$ dan nilai signifikan lebih besar dari nilai alfa. (2) Price earning ratio berpegaruh positif tapi tidak signifikan terhadap return saham PT. Ramayana Lestari Sentosa Tbk. Hal ini dibutkikan dengan hasil uji parsial yang menunjukkan nilai $t_{\text {hitung }}$ lebih kecil dari nilai $t_{\text {tabel }}$ dan nilai signifikan lebih besar dari nilai alfa. (3) Return on investment berpegaruh positif tapi tidak signifikan terhadap return saham PT. Ramayana Lestari Sentosa Tbk. Hal ini dibutkikan dengan hasil uji parsial yang menunjukkan nilai $t_{\text {hitung }}$ lebih kecil dari nilai $t_{\text {tabel }}$ dan nilai signifikan lebih besar dari nilai alfa. (4) Return on equity berpegaruh positif tapi tidak signifikan terhadap return saham PT. Ramayana Lestari Sentosa Tbk. Hal ini dibutkikan dengan hasil uji parsial yang menunjukkan nilai $t_{\text {hitung }}$ lebih kecil dari nilai $\mathrm{t}_{\text {tabel }}$ dan nilai signifikan lebih besar dari nilai alfa. (5) Eraning per share, debt to equity ratio, price earning ratio, return on investment, dan return on equity secara simultan berpengaruh positif tapi tidak signifikan terhadap return saham PT. Ramayana Lestari Sentosa Tbk.

\section{DAFTAR RUJUKAN}

Agnes Sawir. 2005. Analisis Kinerja Keuangan dan Perencanaan Keuangan. Jakarta: PT Gramedia Pustaka Utama

Altman, Edward I. 1968: Financial Ratios, Discriminant Analysis and the Prediction of Corporate Bankruptcy. In: The Journal of Finance, 22(4),589609

Andi Rifqah Purnama Alam, 2018, Analisis Likuiditas Dan Profitabilitas Pada P.T. MNC Land, Tbk, Jurnal Economix Volume 6 Nomor 2, STIE Tri Dharma Nusantara Makassar

Aulia. 2007.Pengaruh Pembiayaan Jual Beli, Pembiayaan Bagi Hasil, dan Rasio Non Performing Financing (NPF terhadap Profitabilitas Bank umum Syariah di Indonesia, Jurnal Fakultas Ekonomi dan Bisnis, Universitas Brawijaya.

Bambang Riyanto. 1995. Dasar-Dasar Pembelanjaan Perusahaan. Yogyakarta: BPFE-Yogyakarta

Bambang, Riyanto. 2002. Dasar-Dasar Pembelanjaan Perusahaan, edisi 4. Yogyakarta: BPFE

Belkaoui, 2003. Teori Akuntansi, Jilid 1, Edisi-2. Jakarta: Penerbit Erlangga.

Djarwanto. 2003. Pokok-Pokok Analisis Laporan Keuangan, Edisi Kedua. BPFE. Yogyakarta

Dyah Kumala Trisnaeni. 2007. Pengaruh Kinerja Keuangan Terhadap Return Saham Perusahaan Manufaktur Yang Terdaftar Di BEJ. Skripsi, Yogayakarta

Edy Sutrisno, 2009, Manajemen Sumber Daya Manusia, Jakarta, Kencana. Pernada Media Group

Erlina, Sri Mulyani, 2007. Metodologi Penelitian Bisnis : Untuk Akuntansi dan. Manajemen, Cetakan Pertama USU Press, Medan

Harahap, 2002. Analisa Kritis Atas Laporan Keuangan, Jakarta : PT. Raja Grfindo Persada

Harahap, 2009. Teori Kritis Laporan Keuangan. Jakarta: Bumi Aksara

Harahap, Sofyan Syafri. 2008. Analisis Kritis Atas Laporan Keuangan. Raja. Grafindo Persada, Jakarta

Helfert. Erich A. 1997., Teknk Analisis Keuangan (Petunjuk Praktis Untuk Mengelola Dan Mengukur Perusahaan). Edisi 8, Erlangga 
Horne, James C. Van dan John M. Wachowicz JR. 2005. Prinsip-Prinsip Manajemen Keuangan, Buku I, Edisi-12. Jakarta: Penerbit Salemba Empat.

Ikatan Akuntan Indonesia, 2007, Standar Akuntansi Keuangan. Jakarta: Salemba. Empat

Ikatan Akuntan Indonesia. 2004. Pernyataan Standard Akuntansi Keuangan, Edisi Ketujuh. Jakarta: Penerbit Salemba Empat.

James C, Van Horne dan John M. Wachowicz. 2005. Prinsip-prinsip Manajemen. Keuangan. Edisi kedua belas. Jakarta: Salemba Empat

Kasmir, 2008, Analisis Laporan Keuangan, Rajawali Pers, Jakarta

Kasmir. (2012), Analisis Laporan Keuangan. Jakarta : PT. Raja Grafindo Persada

Keown. 2004. Manajemen Keuangan : Prinsip-Prinsip dan Aplikasi. Edisi 9,. Indeks. Jakarta

Lukviarman, Niki. 2006, Dasar Dasar Manajemen Keuangan, Andalas University. Press, Padang

Machfoedz, 1994, Pengaruh Rasio Keuangan Terhadap Perubahan Laba, Jurnal Riset Akuntansi Indonesia.

Marginingsih, R. 2017. Penilaian Kinerja Perusahaan dengan Menggunakan Analisa Rasio Keuangan pada Perusahaan Telekomunikasi di Indonesia, Jurnal, Cakrawala, Vol. XVII, No. 1, Maret 2017

Munawir S. 2002. Analisis Informasi Keuangan. Edisi Pertama. Yogyakarta: Liberty Yogya

Munawir, S. 2001. Analisa Laporan Keuangan, Cetakan Kelima. Yogyakarta: Penerbit Liberty.

Munawir, S. 2010. Analisis laporan Keuangan, Edisi keempat. Cetakan Kelima. Belas. Yogyakarta: Liberty

Nainggolan, Pahala. 2004. Cara Mudah Memahami Akuntansi, PPM, Jakarta

Prastowo Dwi dan Rifka Juliaty. 2008. Analisis Laporan Keuangan: Konsep dan Aplikasi (Edisi Kedua). Yogyakarta: UPP STIM YKPN

Rahardjo, Sapto. 2003. Panduan Investasi Obligasi. Jakarta : PT Gramedia.

Resmi, Siti, 2002, Keterkaitan Kinerja Keuangan Perusahaan dengan Return Saham. Kompak. No. 6, September 2002

Reynaldo Hamonangan dan Hasan Sakti Siregar. 2009. Pengaruh Capital Adequacy Ratio, Debt to Equity Ratio, (on Performing Loan, Operating Ratio, dan Loan to Deposit Ratio terhadap Return on Equity (ROE) Perusahaan Perbankan yang terdaftar di Bursa Efek Indonesia. USU. Sumatera Utara
Samsul, Mohammad, 2006, Pasar Modal dan Manajemen Portofolio, Surabaya: Erlangga.

Saraswati, dkk. (2013). Analisis Laporan Keuangan sebagai Alat Penilaian Kinerja Keuangan pada Koperasi (Studi pada Koperasi Universitas Brawijaya Malang periode 2009-2012) Jurnal Fakultas Ekonomi dan Bisnis, Universitas Brawijaya

Soemarso. 2002. Akuntansi Statu Pengantar, Buku 2. Edisi Lima. Jakarta: Salemba Empat

Sofyan Syafri. 2002. Teori Akuntansi: Laporan Keuangan, Cetakan Ketiga.

Suad Husnan, 2003, Manajemen Keuangan Teori dan Penerapan. (keputusan Jangka Pendek), Edisi keempat, BPFE, Yogyakarta

Sugiyono, 2008. Metode Penelitian Kunatitatif Kualitatif dan $R \& D$. Bandung. Alfabeta

Suhendro 2016, Analisis Profitabilitas dan Likuiditas Untuk Menilai Kinerja Keuangan Pada PT Siantar Top Tbk, Jurnal Human Falah: Volume 4. No. 2 Juli

Sundjaja, Ridwan S. dan Inge Barlian, 2001. Manajemen Keuangan Dua. Edisi. Kedua. PT Prehallindo

Sutrisno, Edi. 2009. Manajemen Sumber Daya Manusia Edisi pertama. Jakarta: Kencana Prenada Media Group

Suwardjono, 2003. Pengantar Akuntansi, Edisi 3, Penerbit BPFE Yogyakarta

Syamsuddin. 2009. Manajemen Keuangan Perusahaan. Jakarta: PT. Raja Grafindo. Persada

Vernon Kam. 1986. Accounting Theory. Second Edition. John willey and Sons. Canada

Weston, J. Fred dan Thomas, E. Copeland. 2003. Manajemen Keuangan, Edisi Kedelapan, Penerjemah Kirbrandoko, A. Jaka Wasana M, dan Supranoto Dipokusumo. Jakarta: Penerbit Erlangga

Zainuddin dan Hartono, 1999, Manfaat Rasio Keuangan dalam Memprediksi Pertumbuhan Laba, Jurnal Riset Akuntansi Indonesia. 